\title{
Effect of information quality due accounting regulatory changes: Applied case to Mexican real sector
}

\author{
Efecto en la calidad de la información ante cambios en la normatividad \\ contable: caso aplicado al sector real mexicano
}

Héctor Horacio Garza Sánchez*, Klender Aimer Cortez Alejandro, Alma Berenice Méndez Sáenz, Martha del Pilar Rodríguez García

Universidad Autónoma de Nuevo León, Mexico

Received 17 March 2015; accepted 3 November 2015

Available online 29 May 2017

\begin{abstract}
The purpose of this paper is to examine whether changes in accounting standards improve value relevance of financial information on listed companies in Mexico. The research was conducted for the period 2000-2013 using a sample of 141 companies that report to the Mexican stock exchange using the methodology of panel data. Our findings show that changes in local regulations (generally accepted accounting principles) to internationally approved standards (Financial Reporting Standards and International Financial Reporting Standards) increase the value relevance and therefore the quality of information. The study shows that the accounting information with international Financial Reporting Standards is more trustworthy for foreign and national investors.

(C) 2017 Universidad Nacional Autónoma de México, Facultad de Contaduría y Administración. This is an open access article under the CC BY-NC-ND license (http://creativecommons.org/licenses/by-nc-nd/4.0/).
\end{abstract}

Keywords: Quality of accounting information; Financial Reporting Standards; International Financial Reporting Standards; Accounting principles

JEL classification: B52; C45; K11; L24

\footnotetext{
* Corresponding author.

E-mail address: hfacpya@hotmail.com (H.H. Garza Sánchez).
}

Peer Review under the responsibility of Universidad Nacional Autónoma de México. 


\section{Resumen}

El objetivo de este trabajo es analizar si los cambios en las normativas contables mejoran la relevancia valorativa de la información financiera en empresas cotizadas en México. La investigación se realizó para el periodo de 2000 a 2013 utilizando una muestra de 141 empresas que reportan a la bolsa mexicana de valores utilizando la metodología de datos panel. Nuestros hallazgos muestran que los cambios de normativa locales (principios contables generalmente aceptados) a normativas homologadas internacionalmente (normas de información financiera y normas internacionales de información financiera) aumentan la relevancia valorativa y, por consiguiente, la calidad de la información. Este estudio muestra que la información contable elaborada mediante las normas internacionales de información financiera es más confiable para los inversionistas extranjeros y nacionales.

(C) 2017 Universidad Nacional Autónoma de México, Facultad de Contaduría y Administración. Este es un artículo Open Access bajo la licencia CC BY-NC-ND (http://creativecommons.org/licenses/by-nc-nd/4.0/).

Palabras clave: Calidad de la información contable; Normas de información financiera; Normas Internacionales de Información Financiera; Principios contables

Códigos JEL: B52; C45; K11; L24

\section{Introduction}

The research done regarding the quality of the accounting information is of interest to different agents such as the institutions that issue standards, e.g., the FASB (Financial Accounting Standards Board) or the IASB (International Accounting Standards Board), financial intermediaries, regulatory bodies, researchers and academics, and in general, to the users of financial statements for the making of decisions.

Our work contributes to the debate on whether the adoption of the accounting standards adapted throughout the period of 2000 to 2013 are associated with the improvement of the quality of accounting information. The objective of this work is to analyze if the changes in the accounting standards improve the evaluative relevance of the financial information in listed companies in Mexico. We intend to show if the variables of accounting profit and book value of the net worth are associated with the market value of the companies listed in the Mexican Stock Exchange.

Our discoveries show that the changes from local standards (Generally Accepted Accounting Principles) to internationally homologated standards (International Financial Reporting Standards) increase the evaluative relevance and therefore the quality of the information.

The investigation is divided into five sections; the first one corresponds to the review of the literature where the background of the accounting standards and previous investigations are analyzed. In the second section we present the theoretical framework where we explain definitions and measurements of the accounting quality and of the IFRS (International Financial Reporting Standards). In the third section we present the methodology where we explain the sample, the models to be assessed and the hypotheses. Lastly, the fourth and fifth sections correspond to the results and conclusions, respectively. 


\section{Review of the literature}

\section{Background of the accounting standards}

Nair and Frank (1980) state that in Mexico, the accounting practices and audits have been influenced by the generally accepted principles in the United States of America, with an approach oriented toward the establishment of rules more than standards, however, the Generally Accepted Accounting Principles (GAAP) and the International Financial Reporting Standards (IFRS) have some influence depending on their context of implementation (Schipper, 2003).

The principles specify a guide but require more judgment in their implementation; in turn, the rules contemplate more requirements but leave less room for discretion (Barth, Landsman, Lang, \& Williams, 2007). Regarding the Financial Reporting Standards (FRS), these were adapted to the IFRS, with a more rule-oriented approach.

The accounting activity in Mexico was first regulated by the Instituto Mexicano de Contadores Públicos (IMCP), officially recognized in 1977 and in charge of issuing the accounting standards in Mexico, in bulletins and newsletters of the GAAP. The IMCP created the Patronato para la Investigación y Desarrollo de Normas de Información Financiera, which later evolved to the Consejo Mexicano para la Investigación y Desarrollo de Información Financiera, A.C. (CINIF), formed in 2001 by leading entities of the public and private sectors. It was not until 2004, under the influence of the global trend and with the essential objective of moving forward to a greater convergence with the financial information standards at an international level, when it assumed the role and responsibility to issue the accounting standards in Mexico, called the Financial Reporting Standards (FRS).

In Mexico, the Comisión Nacional Bancaria y de Valores (CNBV), looking to have a balanced development of the financial system and considering the evolution of global markets, has indicated the importance of having a unique set of accounting standards at an international level in order to ensure that the financial information of the entities listed in said markets is determined by the same bases and can be used and compared in any other part of the world. Therefore, it decided to proceed to adapt the International Financial Reporting Standards (IFRS) issued by the CINIF.

In 2009 , the CNBV modified its strategy by deciding to directly adopt the international standards for the exercises that start in 2012; in this sense, it indicates that the issuing entities will have the obligation to elaborate and divulge their financial information based on the IFRS, and the financial statements of issuing entities, trust founders or foreign guarantors, shall be elaborated according to some of the following options: first of all, based on the IFRS that the IASB issues; secondly, based on US-GAAPs, having to incorporate in the corresponding complimentary notes an explicative document on the relevant differences between the accounting standards and the methods used to elaborate their financial statements. However, even though the mandatory date is January 1st, 2012, the issuing entities can adopt them in advance for the exercises of 2008 and 2011.

Due to the foregoing, we can stress that there are three important periods in the implementation of the accounting standards: (1) GAAP until 2005, (2) FRS 2006-2011 and IFRS 2012 to the third quarter of 2013. With these periods, we will analyze the effect that each one of them has on the evaluative relevance and in this same way, on the quality of the accounting information. 


\section{Previous investigations}

The importance of determining the effects of the incorporation of the IFRS complies with the fact that the fundamental information of the company is of quality for the users of financial information. There have been a great number of investigations on the effect that the accounting quality has on the variables of prices and profitability, which have not produced a consensus production, since certain studies (Barth, Landsman, \& Lang, 2008; Bartov, Goldberg, \& Kim, 2005; Bilgic \& İbis, 2013; Dorantes, 2013; Kargın, 2013; Mohan \& John, 2011; Standifird \& Weinstein, 2002) found quality in the financial information, while in other studies there are mixed results. This means that they find quality in utilities but not in capital like in Agostino, Drago, and Silipo (2011) and Jarva and Lantto (2012). Whereas other studies do not find a relation between the accounting variables and the market value (Davis-Friday \& Rivera, 2000; Hung \& Subramanyam, 2007; Morais \& Curto, 2008; Tsalavoutas, André, \& Evans, 2010).

Some studies determine the evaluative relevance by dividing the sample into periods and post-adoption of the IFRS. These analyze the changes of the importance and the slopes of the variables of the profits and the carrying value. Similarly, they mention that if the $R^{2}$ increases after the adoption, then there is relevance. Among the most important of this type of studies are the investigations of Bartov et al. (2005) and Barth et al. (2008).

In a study of companies from 21 countries that adopted the IFRS carried out by Barth et al. (2008), they concluded that the companies that report a low IFRS have a significantly higher $R^{2}$ and exhibit a high association of the accounting figures with the stock price and the stock exchange profitability. The same finding is presented in Morais and Curto (2008), proving that in Europe the listed companies present more evaluative relevance when adopting the IFRS. However, their data include the period of 2000-2005 and does not distinguish between the voluntary and obligatory adoption of the IFRS. In Germany, Bartov et al. (2005) demonstrate that the utility slopes based on IFRS have a higher evaluative relevance than the utility slopes based on the German standard.

For emerging markets such as Warsaw, Budapest and Prague, Standifird and Weinstein (2002) concluded that the companies could improve their legitimacy with the adoption to the international accounting standard. For the Mexican market, Dorantes (2013) examines the relevance of the accounting principles demonstrating that there is an evaluative relevance of the accounting principles.

In India, Mohan and John (2011) examined the evaluative relevance of information and found that the carrying value per stock and earnings per stock have a positive statistical relation with the stock price. Using this same methodology, Kargin (2013) and Bilgic and İbis (2013) found that the carrying value is decisive for the stock price and the market value in Istanbul. Rawashdeh (2003) for the market of Jordan found a significant impact on the stock price after the change in the accounting standard, which provides a greater evaluative relevance to the market, showing more significant results in the smaller companies.

On the other hand, there are studies with mixed results, as there is relevance in the income but not in the capital. Agostino et al. (2011), in their study for 15 European banks, found that the marginal effect (relevance value) of the income increased for the entire sample while the same does not happen with the variable of the capital, the effect of which is negative when introducing the international standard. It also includes a dummy variable that determines that it must be zero when the IFRS is not obligatory and 1 when it is.

Jarva and Lantto (2012) found that, for companies listed in Finland, the earnings under IFRS have a greater effect on the market value of the company than under local standards. Thus they conclude that the carrying value measured under the IFRS does not have a greater evaluative 
relevance than those companies that reported under a local standard and therefore are not of higher quality. This could be due to the explicative capacity of the income, which is an accounting measure of the profitability that measures the capability of a company to make future payments of dividends (Morais \& Curto, 2008).

Lastly, in some investigations we found that the FRS have not affected the quality of the information, Tsalavoutas et al. (2010) concluded that they could not find any significant changes in the evaluative relevance of the carrying value of the capital and of the results of these two periods, in an environment with a weak corporate government such as the Greek market. Hung and Subramanyam (2007) found very little evidence that the IFRS improve the evaluative relevance in the carrying value and in the net result. Davis-Friday and Rivera (2000) state that the reconciliation of accounting information under local standards with the American ones does not have a significant impact on the stock price.

Morais and Curto (2008) conclude, for a sample of Portuguese companies, that by changing the periods of adoption from local Portuguese standards to international standards, it does not improve the effect on the stock price of the earnings per stock or the carrying value of the stock. Similarly, they found that the $R^{2}$ decreases in the implementation period of the IFRS.

These findings are contradictory to the previous literature, which shows that the adoption of the IFRS improves the relevance of the value. However, these results may be justified, as the political and economic influences on the presentation practices of financial reports of the country (Ball, 2006) could affect their transparency as well as the effects of the standards in the quality of the information.

The aforementioned investigations are based on the EMH (efficient-market hypothesis) which states that the markets react rationally to the arrival of new information and the prices vary as it is being received. There are three forms of efficiency in prices as Fama (1970) points out: weak, strong, and semi-strong. In this investigation we undertake the last, which assumes that today's prices reflect all the accessible public information such a dividends, fiscal and financial information, news and information on the status of the economy.

\section{Theoretical framework}

\section{Quality of the accounting information}

The accounting information is used to understand the economic reality of the company in order to make adequate decisions, so that it should be defined through the quality of the same (Dumitru, 2011). Said quality of the accounting information has been receiving greater attention due to the recent accounting scandals. However, despite the increasing importance given to this issue, the quality of accounting remains a vague term which is difficult to define (Bartov et al., 2005; Hribar, Kravel, \& Wilson, 2014).

There are a great number of definitions regarding the concept of the quality of accounting information, from a quantitative approximation the following works stand out: Penamn and Zhang (2002), Dechow and Schrand (2004) and Dechow, Ge, and Schrand (2010), who define high quality through the predictive effect of the accounting income on the future valuation of the company. On the other hand, Barth et al. (2008) state that there is quality in the result when the accounting information is less manipulated, a more opportune acknowledgment of the losses is present, and an increase in the predictive capability is given by the regression between the fundamental and market variables. 
Dechow et al. (2010) mention that there is no measure of quality for all decision models. Other authors such as Ball, Robin, and Wu (2003), Ball and Shivakumar (2005) and Burgstahler, Hail, and Leuz (2006) state that the quality of the accounting information varies according to increase in the number of users that have access to privileged information, as this is how the asymmetry of the information is resolved in private companies.

Despite the lack of a clear definition of the accounting quality, several studies use measures that are considered substitutes of accounting quality, for example, the administration of profits, the opportune acknowledgment of losses and the evaluative relevance (Barth et al., 2008). In our research, we considered the evaluative relevance to measure the quality of the information as in Francis, LaFond, Olsson, and Schipper (2004) and Agostino et al. (2011). The investigation in evaluative relevance has been fundamentally carried out in developed countries. However, there is a lack of evidence in developing countries, like in Latin America and Mexico.

\section{International Financial Reporting Standards}

The IFRS are accounting standards issued by the Financial Accounting Standards Board (IASB), an independent organization with headquarters in London, United Kingdom. They pretend to be a set of rules that, ideally, would be applied in the same manner to the financial reports by the public companies of the world. Between 1973 and 2000, the international standards were issued by the organization that preceded the IASB, the International Accounting Standards Committee (IASC). This organization was created in 1973 by professional associations of accountants in Australia, Canada, Germany, Japan, Mexico, the Netherlands, the United Kingdom and Ireland, and the United States. During this period, the rules of the IASC were described as "International Accounting Standards" (IAS).

Since April 2001, this task of elaborating the standards has been undertaken by a reconstructed IASB. The IASB describes its rules under the new label: "International Financial Reporting Standards" (IFRS), even though it continues to acknowledge (accept as rightful) the previous standards (IAS) issued by the former regulatory organization (IASC), the IASB is better financed, has better personnel and is more independent than its predecessor.

For Ball (2006) there are three advantages to the adoption of the IFRS, firstly they produce economies of scale, given that they are only invented once, they would be a type of public asset, and the marginal cost of their implementation to a new company is zero. The second advantage is that they protect auditors from the manipulation of information by the administrators; and the third advantage is that they allow comparing information between different countries. This third comparability advantage facilitates the cross-border investment and the integration of the capital market (Aggarwal, Klapper, \& Wysocki, 2005).

In the last decade there has been an increasing interest on how the corporate reports are able to mitigate agency problems and the lack of information. The literature (Armstrong, Barth, \& Riedl, 2010; Ball et al., 2003; Rawashdeh, 2003) has attempted to give an answer to issues such as whether international standards produce relevant or quality information for the investors and interested parties. Regarding this issue, for Barth et al. (2008) the IFRS are higher quality standards than the national ones, which could prove to have a "reputational effect" on the companies that voluntarily adopt them.

Although, there could be differences in the implementation of IFRS derived from transparency and enforceability issues. Daske, Hail, Leuz, and Verdi (2007) found that the economic effects of the adoption of the IFRS depend on having a serious commitment to transparency. Similarly, Daske, Hail, Leuz, and Verdi (2008) concluded that the effects of the capital market in the face 
of the changes implemented by the IFRS when they are obligatory only present themselves in countries with strict regimes and where the institutional environment provides strong incentives for the companies to be transparent. It would be expected that the standard changes have a greater positive effect on developed markets.

\section{Methodology}

The sample is comprised by 141 issuing companies of the Mexican Stock Exchange (BMV) during the period of 2000-2013, considering only the real sector. For the purpose of this study, we have consulted the Economática database in order to obtain the quarterly series of accounting and market variables.

In this research we intend to determine whether the fundamental accounting variables have evaluative relevance and, consequently, financial standing in the stock market in Mexico. First of all, we would like to know if there is financial standing in the Mexican market during the study period (2000-2013). To this end, based on the studies of Mohan and John (2011) and Dorantes (2013) we shall determine the significance in EBIT (Earnings before interest and taxes) and of Equity (Equity of the Company). The hypotheses would be as follows:

$H_{a}^{1}$ : the fundamental variables (EBIT and Equity) have an impact in the capitalization of the company.

In addition, we determined if the IFRS, measured as a dichotomous variable, has an impact on capitalization as determined by Agostino et al. (2011) and Cameran, Campa, and Pettinicchio (2014) in their study. Thus, our second hypothesis would be as follows:

$H_{a}^{2}$ : the effect of the IFRS is greater than that of the GAAP and the effect of the FRS is greater than that of the GAAP.

On the other hand, in order to be more conclusive with our results we divided our sample in preand post-adoption of the IFRS as with Bartov et al. (2005) and Barth et al. (2008). Furthermore, we shall demonstrate if increases in the $R^{2}$ exist, and in order to prove this, our third and fourth hypotheses would be as follows:

$H_{a}^{3}$ : The EBIT (Earnings before interest and taxes) and the Equity increase their significance and value by changing the study periods of GAAP to FRS and to IFRS.

$H_{a}^{4}$ : The $R^{2}$ increases after moving from a period of local standards (GAAP and FRS) to a period of international standards (IFRS).

In order to prove the first two hypotheses, we used the full study period, i.e., from 2000 to 2013, and for the third and four hypotheses we identified three periods: (1) GAAP from 2000 to 2005; (2) FRS from 2006 to 2011; and, (3) IFRS from 2012 to the third quarter of 2013. For the latter case the dummy variables were eliminated.

In order to prove the first case, meaning the entirety of the sample, we estimated the model of Eq. (1).

$$
\begin{aligned}
\text { Cap }_{i t}= & \beta_{0}+\beta_{1} \text { PAT }_{i t}+\beta_{2} \text { EBIT }_{i t}+\beta_{3} \text { Rot_Assets }_{i t}+\beta_{4} \text { Size }_{i t}+\beta_{5} \text { Rot_Debt }_{i t} \\
& +\beta_{6} \text { Growth }_{i t}+\beta_{7} \text { FRS }+\beta_{8} F R S+e_{i t}
\end{aligned}
$$

where 
$\mathrm{Cap}_{i t}=$ Market value $^{1}$ of company $i$ of period $t$ deflated with the assets of the period (add formula). Equity $_{i t}=$ Net Worth of the Company $i$ at the moment (add formula) deflated with the assets of the period (add formula).

$E B I T_{i t}=$ Earnings before interest and taxes of company $i$ at moment $t$ deflated with the assets of the period (add formula).

Rot Assets $_{i t}=$ Total sales between the total assets of the company (add formula) in the period (add formula).

Size $_{i t}=$ Natural logarithm of the assets of a company (add formula) in the period (add formula). Rot Debt $_{i t}=$ Yearly rate of change of the total liability of the company (add formula) for the period (add formula) with regard to the period (add formula) using the first logarithmic differences.

Growth $_{t}=$ Yearly rate of change of the sales of the company (add formula) of the period (add formula) with regard to the period (add formula) using the first logarithmic differences.

$F R S_{t}=$ Dichotomous variable that takes a value of 1 if the financial statements of the company (add formula) are prepared in the period (add formula) with standards adapted to the FRS or a value of 0 otherwise.

$I F R S_{t}=$ Dichotomous variable that takes a value of 1 if the financial statements of company $i$ are prepared in period $t$ with standards adapted to the FRS or a value of 0 otherwise.

Following the studies of Kargin (2013), Bilgic and İbis (2013), Agostino et al. (2011) and Kothari and Zimmerman (1995), we considered capitalization as a dependent variable. For the independent variables we selected fundamental accounting variables EBIT and Equity (Dechow \& Schrand, 2004; Dechow et al., 2010; Ohlson, 1995). For the efficiency variable, following Lang, Smith Raedy, and Wilson (2006), we incorporated the variable of asset rotation, which is measured through the annual change of assets.

As control variables we considered the size of the company determined by the natural logarithm of the total assets following Watts (2003), Francis et al. (2004), Ball and Shivakumar (2005) and Khan and Watts (2009). On the other hand, we included debt rotation measured through the variance of the liability (Ahmed, Neel, \& Wang, 2013; Barth et al., 2008; Chen, Tang, Jiang, \& Lin, 2010; Lang et al., 2006; Nikolaev, 2010; Paananen \& Lin, 2009).

We controlled the anticipated effect of future results in the growth of the companies through the growth variable measured through the rate of change of sales. In this sense, Khan and Watts (2009) sustain that companies with high growth show more volatility in stock performance, are more prone to having large losses, and thus they assert that there is a positive relation between this variable and the stock price. As with our fundamental variables, we hope that the control variables have a greater relation with the market variable insofar as it improves the quality of the information.

On the other hand, we considered all the sample periods in order to generalize the results, and incorporated two dichotomous variables, the first (FRS) takes a value of 1 if the financial statements are prepared with standards adapted to the FRS or a value of 0 otherwise, and the second variable (IFRS), which takes a value of 1 if the financial statements are prepared with standards adapted to the IFRS or a value of 0 otherwise.

Due to the fact that the accounting standards for the case of Mexico have been approved toward an international context, we intend to prove if the evaluative relevance improves with the course

\footnotetext{
${ }^{1}$ In order to calculate the market value, the stock price is multiplied by the number of stock in circulation for each issuer.
} 
Table 1

Correlation coefficients of the variables.

\begin{tabular}{lllllll}
\hline & EBIT & Equity & Size & Rot_Asset & Growth & Rot_Debt \\
\hline EBIT & 1.000 & 0.270 & 0.283 & 0.267 & 0.151 & 0.124 \\
Equity & 0.270 & 1.000 & -0.042 & 0.013 & 0.101 & 0.108 \\
Size & 0.283 & -0.042 & 1.000 & 0.006 & 0.109 & 0.069 \\
Rot_Asset & 0.267 & 0.013 & 0.006 & 1.000 & 0.078 & -0.022 \\
Growth & 0.151 & 0.101 & 0.109 & 0.078 & 1.000 & 0.374 \\
Rot_Debt & 0.124 & 0.108 & 0.069 & -0.022 & 0.374 & 1.000 \\
\hline
\end{tabular}

Source: Author's own computation using Eviews 7.

of time, for which we estimated three models divided through the implementation of the different standards that have been implemented in Mexico, having identified three periods: (1) GAAP from 2000 to 2005; (2) FRS from 2006 to 2011; and (3) IFRS from 2012 to the third quarter of 2013. The proposed model is presented through the following equation:

$$
\begin{aligned}
\text { Cap }_{i t}= & \beta_{0}+\beta_{1} \text { PAT }_{i t}+\beta_{2} \text { EBIT }_{i t}+\beta_{3} \text { Rot_Assets }_{i t}+\beta_{4} \text { Size }_{i t} \\
& +\beta_{5} \text { Rot_Debt }_{i t}+\beta_{6} \text { Growth }_{i t}+e_{i t}
\end{aligned}
$$

We will contrast our hypotheses using the panel data methodology with the help of the Eviews software for panel data. Due to the heterogeneity of our observations with regard to the companies, we assumed a heteroscedastic presence in this sense and therefore we employed generalized least squares. Likewise, in order to prove the accounting relevance, we considered if the $R^{2}$ statistic increases with the passage of time.

\section{Results}

Considering the 2000-2013 study period for 141 units, the correlation was calculated between independent variables in order to detect a possible multicollinearity between said variables. The values are relatively small indicating a low correlation between the variables, that is, there are no signs of multicollinearity (Table 1 ).

Table 2 shows the results of the analysis of the panel data model, ${ }^{2}$ as can be observed all the fundamental variables of the model are positive and significant with a $95 \%$ reliability, ${ }^{3}$ with which we prove the first hypothesis. Regarding the dichotomous variables, we found that they are statistically significant, thus confirming that there is an increase in the relevance of the accounting information when changing the standards.

Regarding the impact of the implementation of the FRS vs IFRS we find that the coefficient of the IFRS is of 41.3 when compared with that of the GAAP. On the other hand, the coefficient of the FRS is 28.8 greater than that of the GAAP. ${ }^{4}$ In general terms, given this finding, it can be

\footnotetext{
${ }^{2}$ The White period standard errors \& covariance correction was utilized, this is a tool designed to fix the serial correlation and the variations in the time of the errors, which are common in panel data.

${ }^{3}$ Model estimations with fixed and random effects were considered, with fixed effects in cross section units being the most appropriate under the Hausmann test. However, the results were not overly different from those presented in this article and the control variations, size and Rot_Assets, were not significant, and therefore it was opted to consider the panel data model considering panel data with the correction of weights in a cross section.

${ }^{4}$ This result was validated by implementing the Wald test taking into consideration the following hypothesis Ho: $\mathrm{B}(\mathrm{IFRS})-\mathrm{B}(\mathrm{FRS})=0$, which was rejected.
} 
Table 2

Estimate of the sample for 2000-2013.

\begin{tabular}{|c|c|c|c|c|}
\hline Cap & Coefficients & Standar error & $T$ statistic & p_value \\
\hline$E B I T$ & 2.1839 & 0.3672 & 5.9472 & 0.0000 \\
\hline Equity & 1.1531 & 0.1077 & 10.7074 & 0.0000 \\
\hline Size & 8.5837 & 1.2619 & 6.8019 & 0.0000 \\
\hline Rot_Assets & 0.1297 & 0.0389 & 3.3257 & 0.0009 \\
\hline Growth & 0.1626 & 0.0560 & 2.9010 & 0.0037 \\
\hline Rot_Debt & 0.1783 & 0.0472 & 3.7730 & 0.0002 \\
\hline IFRS & 41.3077 & 5.5656 & 7.4218 & 0.0000 \\
\hline$F R S$ & 28.8802 & 3.6747 & 7.8591 & 0.0000 \\
\hline Cons & -158.5610 & 20.7991 & -7.6234 & 0.0000 \\
\hline$R^{2}$ & 0.5619 & & $N$ & 3231 \\
\hline
\end{tabular}

Source: Author's own computation using Eviews 7.

understood that the IFRS have a greater impact than the FRS considering the estimated coefficient for these variables in the model and in turn these two have a greater impact than the GAAP. These results show the importance of the market to the implementation of approved standards in an international context.

Our results are consistent with Rawashdeh (2003), Bartov et al. (2005) and Barth et al. (2008), who find that with higher quality standards the evaluative relevance of the accounting information increases, and contrary to Hung and Subramanyam (2007) and Tsalavoutas et al. (2010). We can argue that, based on the results, the public companies in Mexico have benefited with a greater reputation by changing from local to international standards. The effects in the capital market would be a greater capital of foreign investors who look for companies that reveal financial information based on international standards, thus mitigating the problems of transparency and lack of information.

In order to validate the third and fourth hypothesis we considered the model of Eq. (2) for each of the periods in order to analyze each one of them separately. The studies by Rawashdeh (2003) and Agostino et al. (2011) suggest dividing the sample in various periods considering the change of standard; if there is growth in the coefficients of the fundamental values such as EBIT and Equity, then the impact of the change of standard is proven given that, in principle, it would be improving the relevance of the accounting information; if, in addition, the $R^{2}$ increases, it would further support the hypothesis that the relevance improves.

The results are shown in Table 3. The fundamental accounting variables, Equity and EBIT, are positive and significant considering a 95\% reliability in the three periods. Regarding the control variables, they are all significant with $90 \%$ and $95 \%$ of importance, except for the variable stock rotation for the period of the FRS, much like the findings of Paananen and Lin (2009), who find no evidence in this variable. Therefore, we obtain evidence that the investors value the information contained in the financial statements in Mexico. Our results are consistent with Bartov et al. (2005) and Barth et al. (2008).

The results also show that the evaluative relevance also increases with the adoption of the FRS. This is due to the fact that when passing from the period of the GAAP to the FRS, the $R^{2}$ has an increase of $14 \%$, which indicates an improvement in the evaluative relevance. Regarding the impact of the fundamental variables, we can observe that only $50 \%$ of the estimated coefficients increased during these two periods, however, the two fundamental variables (EBIT and Equity) increased. This tells us that the quality of the information improves, which in turn improves 
Table 3

Models for each of the periods.

\begin{tabular}{|c|c|c|c|c|c|c|}
\hline & \multicolumn{2}{|l|}{ GAAP } & \multicolumn{2}{|l|}{ FRS } & \multicolumn{2}{|l|}{ IFRS } \\
\hline & Coefficient & $p$-value & Coefficient & $p$-value & Coefficient & $p$-value \\
\hline$E B I T$ & 0.3294 & 0.3666 & 3.6411 & 0.0000 & 3.0880 & 0.0000 \\
\hline Equity & 0.5764 & 0.0000 & 1.2558 & 0.0000 & 1.7742 & 0.0000 \\
\hline Size & 2.6754 & 0.0072 & 7.2089 & 0.0000 & 11.3044 & 0.0021 \\
\hline Rot_Assets & 0.0941 & 0.0208 & 0.0510 & 0.1097 & 0.1531 & 0.0000 \\
\hline Growth & 0.3317 & 0.0004 & 0.1207 & 0.0012 & 0.0896 & 0.0908 \\
\hline Rot_Debt & 0.1589 & 0.0135 & 0.0000 & 0.0021 & 0.2194 & 0.0024 \\
\hline Cons & -34.7371 & 0.0431 & -115.7754 & 0.0000 & -195.8749 & 0.0000 \\
\hline$R^{2}$ & \multicolumn{2}{|c|}{0.4992} & \multicolumn{2}{|c|}{0.5654} & \multicolumn{2}{|c|}{0.8188} \\
\hline$N$ & \multicolumn{2}{|c|}{713} & \multicolumn{2}{|c|}{1961} & \multicolumn{2}{|c|}{557} \\
\hline
\end{tabular}

Source: Author's own computation using Eviews 7.

the predictive ability of the fundamental variables (Barth et al., 2008) and thus decreases the asymmetry problems of the information (Ball \& Shivakumar, 2005; Ball et al., 2003; Burgstahler et al., 2006).

In the case of the change of the FRS to the IFRS we find that the $R^{2}$ also increases, but with a greater growth of $44 \%$. This suggests that the adoption of international standards betters the quality of the accounting information. However, the analysis period considered in the IFRS is small in contrast with that of the FRS, thus, a new model was implemented in the case of the FRS taking into account only the impact on the adoption, i.e., only the first 7 quarters in order to be comparable. The results are shown in Table 4.

If we only consider the first 7 quarters, the $R^{2}$ increased in the period of the FRS; though even then, the $R^{2}$ in the IFRS model was greater, i.e., the initial impact of the IFRS was greater than that of the FRS with regard to the quality of the accounting information. Regarding the impact of the two fundamental variables, Equity increased whereas EBIT decreased; though this decline was of only $17 \%$, it could perhaps be explained with the external financial environment given that during the first seven quarters of the period of the FRS the results of the companies did not reflect the international financial crisis of 2008 and the economic situation in Europe in the subsequent periods. In this regard, Davis-Friday and Gordon (2002) note that the Equity

Table 4

Models for the first 7 quarters of the regulation.

\begin{tabular}{|c|c|c|c|c|}
\hline & \multicolumn{2}{|l|}{ FRS } & \multicolumn{2}{|l|}{ IFRS } \\
\hline & Coefficient & $p$-value & Coefficient & $p$-value \\
\hline$E B I T$ & 3.7567 & 0.0000 & 3.0880 & 0.0000 \\
\hline Equity & 1.0727 & 0.0000 & 1.7742 & 0.0000 \\
\hline Size & 7.5355 & 0.0000 & 11.3044 & 0.0000 \\
\hline Rot_Assets & 0.1063 & 0.0510 & 0.1531 & 0.0021 \\
\hline Growth & 0.1575 & 0.1207 & 0.0896 & 0.0908 \\
\hline Rot_Debt & 0.5242 & 0.0000 & 0.2194 & 0.0024 \\
\hline Cons & -112.8425 & 0.0000 & -195.8749 & 0.0000 \\
\hline$R^{2}$ & \multicolumn{2}{|c|}{0.6781} & \multicolumn{2}{|c|}{0.8188} \\
\hline$N$ & \multicolumn{2}{|c|}{596} & \multicolumn{2}{|c|}{557} \\
\hline
\end{tabular}

Source: Author's own computation using Eviews 7. 
maintains its significance and explicative power during the crisis, and that the EBIT stops providing informative content, which is attributed to the presence of negative results.

\section{Conclusions}

The market carries out its assessments differently depending on the standard implemented in its development. We determined the quality of the accounting standard measured through an increment in the evaluative relevance of the financial information. In this sense, the reliability in the accounting standards has increased since 2006, year in which the Generally Accepted Principles stopped being used and were adapted to the International Financial Reporting Standards creating the Financial Reporting Standards (FRS).

This study offers important contributions for the Mexican market. First of all, foreign and national investors have certain skepticism regarding the transparency of the companies when divulging their accounting information and of the institutions responsible of monitoring the adoption of the accounting regulations (Dorantes, 2013). In this sense, our results show that the coefficients of the fundamental and control variables are significant, furthermore, the two dichotomous variables (FRS and IFRS) are also significant and positive, with the coefficient of the IFRS variable being greater than the coefficient of the FRS. This shows that the changes in the accounting standards have an impact on the quality of the information during the study period of 2000-2013, with the period of the IFRS having the greater relevance than that of the FRS. With these results, some tranquility can be provided to the investors with regard to our institutions and the transparency of our companies.

Second of all, with the purpose of demonstrating a greater importance in our results and valuing the adaptation of the FRS and IFRS, we opted to cut the period in these two cases with the purpose of finding the effect in the 7 quarters after the adoption of each of these standards. Our results show that the change with greater impact in the evaluative relevance is produced when the IFRS are adapted, having been measured through the increase in the coefficients of the fundamental variables and the predictive capability of the model $\left(R^{2}\right)$, which shows that the work of the CINIF has been effective; our results are similar to those obtained by Bartov et al. (2005) and Barth et al. (2008).

Third of all, regarding the advantages of the incorporation of the IFRS based on Ball (2006) and which were able to be transferred to the Mexican market on the basis of our findings, it could be that the investors could enjoy of more precise, complete and timely information that allows them to have less information asymmetry and thus decrease the problems of risk. Furthermore, the incorporation of the IFRS improved the processing of information, which betters the efficiency in the markets and the reflection of the accounting information on the stock prices. It also reduces the international comparability differences, which could eliminate barriers in acquisitions and divestments, compensating investors with an increase in the acquisition premiums.

Fourth, the IFRS allow for greater quality accounting information, which improves transparency and the corporative government. Due to the fact that the IFRS are based on regulations (Barth et al., 2007), the administrators are more controlled in the manipulation of information and thus could present less agency problems, all for the benefit of the stockholders. Finally, the recognition of losses in an opportune manner results in the administrators being able to have information faster regarding the investments that are generating losses and thus navigate to investments that generate positive VPNs (Ball \& Shivakumar, 2005).

Finally, our findings prove the need to dedicate additional efforts to achieve a unique set of accounting standards accepted in the capital markets at an international level in order to make 
sustainable the transparency made possible by both the FRS and the IFRS. We can thus conclude two things, on the one hand, investors can reliably consider accounting information as an investment criterion, on the other, company administrators must become aware that the fundamental variables of the companies can benefit or harm the market performance of the same, and thus it is necessary that companies have a sustainable financial performance.

\section{References}

Ahmed, A. S., Neel, M. J., \& Wang, D. D. (2013). Does mandatory adoption of IFRS improve accounting quality? Preliminary evidence. Contemporary Accounting Research, 30(4), 1344-1372. http://doi.org/ 10.1111/j.1911-3846.2012.01193.x

Aggarwal, R., Klapper, L., \& Wysocki, P. P. (2005). Portfolio preferences of foreign institutional investors. Journal of Banking \& Finance, 29, 2919-2946. http://doi.org/10.1016/j.jbankfin.2004.09.008

Agostino, M., Drago, D., \& Silipo, D. (2011). The value relevance of IFRS in the European banking industry. Review of Quantitative Finance and Accounting, 36(3), 437-457. http://doi.org/10.1007/s11156-010-0184-1

Armstrong, C., Barth, M., \& Riedl, E. (2010). Market reaction to the adoption of IFRS in Europe. The Accounting Review, 85, 31-61. http://doi.org/10.2308/accr.2010.85.1.31

Ball, R. (2006). International Financial Reporting Standards (IFRS): Pros and cons for investors. Accounting and Business Research, 36, 5-27. http://doi.org/10.1080/00014788.2006.9730040

Ball, R., Robin, A., \& Wu, J. S. (2003). Incentives versus standards: Properties of accounting income in four East Asian countries, and implications for acceptance of IAS. Journal of Accounting and Economics, 36(1-3), 235-270. http://doi.org/10.1016/j.jacceco.2003.10.003

Ball, R., \& Shivakumar, L. (2005). Earnings quality in UK private firms: Comparative loss recognition timeliness. Journal of Accounting and Economics, 39(1), 83-128. http://doi.org/10.1016/j.jacceco.2004.04.001

Barth, M. E., Landsman, W. R., Lang, M., \& Williams, C. (2007). Accounting quality: International Accounting Standards and US GAAP, Working paper. Stanford: Stanford University, University of North Carolina.

Barth, M. E., Landsman, W. R., \& Lang, M. H. (2008). International accounting standards and accounting quality. Journal of Accounting Research, 46(3), 467-498. http://doi.org/10.1111/j.1475-679x.2008.00287.x

Bartov, E., Goldberg, S. R., \& Kim, M. (2005). Comparative value relevance among German, U.S. and International Accounting Standards: A German stock market perspective. Journal of Accounting Auditing and Finance, 20(2), 95-119. http://doi.org/10.2139/ssrn.316525

Bilgic, F., \& Ibis, C. (2013). Effects of new financial reporting standards on value relevance - A study about Turkish stockmarkets. International Journal of Economics and Finance, 5(10), 126-140. http://doi.org/10.5539/ijef.v5n10p126

Burgstahler, D., Hail, L., \& Leuz, C. (2006). The importance of reporting incentives: Earnings management in European private and public firms. The Accounting Review, 81(5), 983-1016. http://doi.org/10.2308/accr.2006.81.5.983

Cameran, M., Campa, D., \& Pettinicchio, A. (2014). IFRS adoption among private companies: Impact on earnings quality. Journal of Accounting, Auditing \& Finance, 29(3), 278-305. http://doi.org/10.1177/0148558x14534260

Chen, H., Tang, Q., Jiang, Y., \& Lin, Z. (2010). The role of international financial reporting standards in accounting quality: Evidence from the European Union. Journal of International Financial Management \& Accounting, 21(3), 220-278. http://doi.org/10.1111/j.1467-646x.2010.01041.x

Davis-Friday, P. Y., \& Gordon, E. A. (2002). The effect of macroeconomic changes on the value relevance of accounting information: The case of Mexico and the 1995 financial crisis. Indiana: University of Notre Dame y Rutgers University. http://doi.org/10.2139/ssrn.322762

Davis-Friday, P. Y., \& Rivera, J. M. (2000). Inflation accounting and 20-F disclosures: Evidence from Mexico. Accounting Horizons, 14(2), 113-135. http://doi.org/10.2308/acch.2000.14.2.113

Daske, H., Hail, L., Leuz, C., \& Verdi, R. (2007). Adopting a label: Heterogeneity in the economic consequences of IFRS adoptions, Working paper. University of Pennsylvania and University of Chicago. http://doi.org/ 10.1111/1475-679x.12005

Daske, H., Hail, L., Leuz, C., \& Verdi, R. (2008). Mandatory IFRS reporting around the world: Early evidence on the economic consequences. Journal of Accounting Research, 46(5), 1085-1142. http://doi.org/10.1111/ j.1475-679x.2008.00306.x

Dechow, P. M., Ge, W., \& Schrand, K. (2010). Understanding earnings quality: A review of the proxies, their determinants and their consequences. Journal of Accounting and Economics, 50(2-3), 344-401. http://doi.org/10.1016/j.jacceco.2010.09.001 
Dechow, P. M., \& Schrand, K. (2004). Earnings quality. Charlotte ville, VA: Research Foundation Publications.

Dorantes, C. (2013). The relevance of using accounting fundamentals in the Mexican stock market. Journal of Economics, Finance and Administrative Science, 18(Special Issue), 2-10. http://doi.org/10.1016/s2077-1886(13)70024-6

Dumitru, G. (2011). The accounting information quality concept. Journal of Academic Research in Economics, 3(3), $559-569$.

Fama, E. (1970). Efficient capital markets: A review of theory and empirical work. The Journal of Finance, 25(2), $383-417$. http://doi.org/10.2307/2325486

Francis, J., LaFond, R., Olsson, P. M., \& Schipper, K. (2004). Costs of equity and earnings attributes. The Accounting Review, 79(4), 967-1010. http://doi.org/10.2308/accr.2004.79.4.967

Hribar, P., Kravel, T., \& Wilson, R. (2014). A new measure of accounting quality. Review of Accounting Studies, 19, 506-538. http://doi.org/10.1007/s11142-013-9253-8

Hung, M., \& Subramanyam, K. (2007). Financial statement effects of adopting international accounting standards: The case of Germany. Review of Accounting Studies, 12(4), 623-657. http://doi.org/10.1007/s11142-007-9049-9

Jarva, H., \& Lantto, A.-M. (2012). The information content of IFRS versus domestic accounting standards: Evidence from Finland. The Finnish Journal of Business Economics, 2, 141-177. http://doi.org/10.2139/ssrn. 1588087

Kargin, S. (2013). The impact of IFRS on the value relevance of accounting information: Evidence from Turkish firms. International Journal of Economics and Finance, 5(4), 71-80. http://doi.org/10.5539/ijef.v5n4p71

Khan, M., \& Watts, R. L. (2009). Estimation and empirical properties of a firm-year measure of accounting conservatism. Journal of Accounting and Economics, 48(2-3), 132-150. http://doi.org/10.1016/j.jacceco.2009.08.002

Kothari, S. P., \& Zimmerman, J. L. (1995). Price and return models. Journal of Accounting and Economics, 20 (2), $155-192$. http://doi.org/10.1016/0165-4101(95)00399-4

Lang, M., Smith Raedy, J., \& Wilson, W. (2006). Earnings management and cross listing: Are reconciled earnings comparable to US earnings? Journal of Accounting and Economics, 42(1-2), 255-283. http://doi.org/10.1016/ j.jacceco.2006.04.005

Mohan, N., \& John, F. (2011). Value relevance of accounting information - An Indian perspective. Journal of Finance, Accounting and Management, 2(1), 16-26.

Morais, A. I., \& Curto, D. J. (2008). Accounting quality and the adoption of IASB standards, Portuguese evidence. Revista Contabilidade and Financas, 19(48), 103-111. http://doi.org/10.1590/s1519-70772008000300009

Nair, R. D., \& Frank, W. G. (1980). The impact of disclosure and measurement practices on international accounting classifications. The Accounting Review, 55, 426-450. http://doi.org/10.1016/b978-0-408-10841-6.50010-5

Nikolaev, V. V. (2010). Debt covenants and accounting conservatism. Journal of Accounting Research, 48(1), 51-89. http://doi.org/10.1111/j.1475-679x.2009.00359.x

Ohlson, J. A. (1995). Earnings, book values, and dividends in equity valuation. Contemporary Accounting Research, 11(2), 661-687. http://doi.org/10.1111/j.1911-3846.1995.tb00461.x

Paananen, M., \& Lin, H. (2009). The development of accounting quality of IAS and IFRS over time: The case of Germany. Journal of International Accounting Research, 8(1), 31-55. http://doi.org/10.2308/jiar.2009.8.1.31

Penamn, S., \& Zhang, X. (2002). Accounting conservatism, the quality of earnings, and stock returns. The Accounting Review, 77(2), 237-264. http://doi.org/10.2308/accr.2002.77.2.237

Rawashdeh, M. (2003). Effects of introducing international accounting standards on Amman stock exchange. Journal of American Academy of Business, 3(1), 361-366.

Schipper, K. (2003). Principles-based accounting standards. Accounting Horizons, 17, 61-72. http://doi.org/ 10.2308/acch.2003.17.1.61

Standifird, S. S., \& Weinstein, M. (2002). Establishing legitimacy in emerging markets: An empirical comparison of the Warsaw, Budapest, and Prague stock exchanges. Journal of Comparative Policy Analysis, 4(2), $143-163$. http://doi.org/10.1080/13876980208412676

Tsalavoutas, I., André, P., \& Evans, L. (2010). Transition to IFRS and value relevance in a small but developed market: A look at Greek evidence, working paper. Stirling: University of Stirling y ESSEC Business School. March 1.

Watts, R. L. (2003). Conservatism in accounting Part II: Evidence and research opportunities. Accounting Horizons, 17(4), 287-301. http://doi.org/10.2308/acch.2003.17.4.287 